\title{
Technology and Education: A Deterministic and Instrumentalist Philosophical Approach
}

\author{
Abdul Shukor Shamsudin ${ }^{1}$, Ayotunde Adetola Adelaja ${ }^{1 *}$, Taofeek Adejare Owoseni ${ }^{2}$ \\ ${ }^{1}$ Universiti Utara Malaysia Sintok, Kedah State, Malaysia \\ ${ }^{2}$ Baze University, Abuja \\ *Corresponding author. Email: ayoadelaja@live.com
}

\begin{abstract}
Over the past few decades, enormous studies examining the significant contribution of technology adoption and usage in the education industry have emerged. Albeit, miniatures of this literature tend to focus on the outcome of massive (total) dependence of these technologies. To achieve the study objective, the authors engage instrumentalism, and determinism, philosophical approaches to investigate the potential outcome of full dependence of education technology in the pedagogical process in the education industry. Exhuming works of literature on technology adoption and usage in the education industry, and how the two philosophical approaches are being used in the field of philosophy, the conceptual findings reveal that using the instrumentalism approach to identify the potential outcome of educational technologies for the pedagogical process, there are bigger chances of producing a high level of effective and efficient students over traditional education. However, complete technology usage can be a complete disaster for the education industry if education is commercialized to the extent that students view education as a determining substance with lesser value. With this, the authors remark that education management should envision and present education technological adoption and usage as a mediating substance that the students needed to reach greater heights.
\end{abstract}

Keywords: determinism, education industry, education technology, instrumentalism, philosophy

\section{BACKGROUND}

The significant role of education cannot be underestimated. Educated minds are capable of seamlessly changing the world and make it a better place to live. Through education, countless innovations and creativity have emerged over time. Over the decades, the education industry has witnessed several changes in terms of policies not limited to internationalization, blended and flexible learning, structure, delivery method, and the recent fourth industrial revolution 'IR 4.0' $[1,2]$.

Despite the several changes brought to our society by the educated minds, the education industry remains among the industry that least experience and is adamant about changing. The teaching mode remains arguably the same since education has been formalized [3, 4]. Some few decades back, the industry has adopted a significant amount of technologies to enhance the pedagogy process. However, comparing the technological adoption rate in the education industry with industries such as health, transportation, and agriculture, the adoption rate seems to be on a lesser side $[5,6,7]$.

Technologies adoption in the education industry has, over the years, present some significant benefits. Examples of which include limiting the barriers of accessing educational institutions across the globe. That is, someone is a remote area can easily access ongoing live lectures in the cities. As 
such, scholars have been keen on examining the effect of these technologies on several educational aspects. For example, the effects of technology on students' behavior $[8,9]$, students' performance $[10$, $11]$, and pedagogical effectiveness or cognition [12].

Findings from these investigations had yielded continuous debates in the education industry. Therefore, giving births to two different emerging schools of thought, 1) technologies as a positive channel to achieve educational success $[13,14,15]$. 2) technologies as distractions and barriers to deep engagement, having a negative influence on students' performance [16, 17].

Notably, the ongoing arguments concerning technology's effect on students' education lead to the creation of several education policies not limited to, 1) the restriction of technological devices that includes the likes of laptops, smartphones, iPads, tablets among other gadgets, in some educational institutions or when the lectures are ongoing. On the other hand, other institutions encourage technology usage for educational purposes irrespective of the time or functions. With these ongoing issues and arguments, the education industry can be argued to be among the industry that is disillusioned in adopting technologies for its 'process' operations.

Further insights into the available earlier studies reveal that educational technologies at any education level were examined as channels supporting traditional education pedagogy $[8,13$, $14,17]$

Meanwhile, consideration into the recent global happening 'COVID-19 pandemic' has caused a paradigm shift in the sense that the educational industry has limited chances of survival without the massive adoption and dependence on technology to carry out its primary teaching activities' pedagogical process.' Considering the recent paradigm shift from technology as a support system to full dependence on technology, the objective of this paper is, therefore, to conceptually argue the consequences of the paradigm shift from the lens of determinism and instrumentalist philosophical thoughts.

\section{PHILOSOPHY OF TECHNOLOGY IN THE EDUCATION INDUSTRY}

Technology adoption among educational institutions is gaining more attention as the day passes by. Its objectives, usage, and engagement among educational institutions remain the same. However, the subjective perception of its effects, consequences, and usage varies among different educational actors, resulting in several viewpoints (philosophy).

The philosophy of technology adoption in education is synonymous with the illustration of a Necker cube given by philosopher Ihde. The interpretation people give to the object 'cube' is based on the angle in which it is being viewed. Hitherto, retaining its objective interpretation, irrespective of how it is being considered. In this study context, technology represents Ihde's Necker cube, while technology applications are how the cube is seen. Thus, the arguments of technologies adoption on education, be it positive or negative, can, therefore, be subjectively true. Nevertheless, one should bear it in mind the flow of education inputs, processes, and outputs change not irrespective of the magnitude of technological adoption [18].

From a phenological viewpoint, Ihde classifies the relationship between human, environment, and technology into seven relationships, namely, mutual constitution, background relations, hermeneutic relations, and embodiment relations. These relationships present a different perception of how we see or perceive the technological effect [55]. These relationships present the world view and objectivity on the relationship between humans and technology $[19,20]$.

The technological adoption process at any educational level is almost the same at every institution. For example, the adoption of social media to support the traditional education and not the 'full' adoption of technologies in an automated form is what we are experiencing today as a result of the global pandemic where physical school activities ranging from pedagogical process to library use are somehow fully automated $[21,22$, 23].

Considering this, the objectives of this conceptual study tend towards determining the perceived outcomes of full technology adoption in the 
education industry on students' performance, efficiency, and effectiveness in the labor market. To our best knowledge, studies in this regard are at their infancy stage. To achieve these stated objectives, the researchers employed the instrumentalist and deterministic philosophy approaches by Carl Jasper and Hadeggar philosophies on technology.

\section{TECHNOLOGY IN THE EDUCATION INDUSTRY}

The use of internet services has gradually redefined the educational process. Thus, some critical educational services such as application and enrolment processes are no more carried out via traditional use of paper and pen but had virtually been moved to conventional approaches over the Internet.

Although educational services such as learning and teaching 'pedagogy' had also been conducted over the Internet. Albeit several studies had investigated e-learning, education technology adoption, factors that enhance, contribute, or influence users to study using contemporary technologies [24, 25]. These studies can be categorized as process studies that are only concerned with technology adoption, with fewer scholars given attention to the results or consequences of technology usage in the education industry [26].

\section{DEBATES ON THE EFFECTS OF EDUCATIONAL TECHNOLOGIES.}

Technologies in the education industry are numerous. However, for clarity and simplification, education technology in this study is reduced to electronic gadgets such as laptops, smartphones, iPads, tablets, and social media sites. All these are standard technologies used in supporting conventional education and, they are also the dominant platform used for the pedagogical process during this trying time via the Internet.

Most of the available studies on technological adoption in the educational industry examine technology as an educational support system. Nevertheless, their philosophical view can be categorized under the instrumentalist view because they believed that pedagogical technologies are channels to attain high cognitive level, support the learning process among students enhance their behavior, self-esteem and study performance in the classroom [27, 28, 29, 30, 31, 32].

Investigating the behavior of students on technology adoption and the pedagogical process by employing a control and treatment group, the study of [28] supports both deterministic and instrumentalist view of technology among the samples (teachers) surveyed. [28] argue that the introduction of technology causes a transformative approach to teaching in some teachers while the students perceive a shift in their learning behavior via interactive, media-rich, and exciting new environment.

Critics of educational technologies have it that the use of technologies has reshaped the socialization among both students and academic staff, limiting the contact barriers, yet, no real relationship could be established [33, 34, 35]. Meanwhile, technology advocates pen the importance and usefulness of pedagogical technologies to be; accessing information about the subject matter, ability to multitask, increase cognitive because of the interactive and colorful environment [28, 29]. Contrarily, [36, 37] are critical on the significant negative relationship between multitasking and students' classroom performance measured by cumulative grade point average (CGPA), selfregulated learning, and self-esteem.

\section{DETERMINISM VIEW OF TECHNOLOGY}

The determinist view of technology argues that man cannot and will not control technology. This school of thought believed technology is autonomous, and it is controlling man, and it is, therefore, shaping their history [38]. Under the view of technology as determinist, [39] argues technology to be the principal actor that brings social changes to man's social life. For example, the advent of the Internet and the new media has transformed human socialization, communication, and knowledge sharing.

Similarly, technology such as those found in the transportation system have significantly redesigned human settlement, mode of transportation and has dictates public infrastructures that include road signs, road shapes and types of house that can be built in a particular area [40, 41, 42]. One of the founders of the determinist view, Heidegger posited 
three claims on technology determinism. These are, 1) technology is not an instrument and can never be an instrument; instead, it is a way of understanding the world; 2) technology is beyond human control. Thus, it cannot be human activity; 3 ) it is known to be the most dangerous that risk us to see through the lens of technology.

Under the determinist technological view, there are thoughts that, at one point, through the negligence and ignorance nature of man technology will take over, and this will be the end of humankind [43, 44]. This is because the technologies we have developed in a way in which human beings never expect; thus, humans are less prepared for its consequences. Examples of this type of technology is that of polythene bags popularly called plastic bags. Through technology, the polythene bags are produced in multitude via the innovative process. However, the consequences of this innovation include land pollution that enhances global warming $[45,46]$.

In the education system, such innovativeness is happening. [47] referred to these phenomena are sometimes as commercialization of the education system. Several education institutions are now offering certified causes with less attention to students' prior qualifications or students' intellectual capacity. The danger here is, sooner or later, if this is not checked, yes, there will be many graduates with less required educational skills; as such, the educational value is in danger. Considering the unforeseen consequences of technologies instead of presenting education institutions as being advanced by adopting and implementing several pedagogical technologies, what should be a significant concern is the result of such adoption on a broader sense and not just institution advancement.

\section{INSTRUMENTALIST VIEW OF TECHNOLOGY}

Contrary to the determinist view that upholds the notion that technology innovation autonomously dictates our social life. Instrumentalist approach sees technology as a tool or the channel man use in achieving their goals after having a clear understanding of the complex interrelationship between man and his environment $[49,50]$. In this type of relationship, technology adheres to the command and responds to the impulses generated in a different place. Examples of this type of relationship is that between man and car. Instrumentalists argue that man is in control of the car; therefore, they drive it at their wish and desire to visit any place of interest. Conferring to the definition given by Carl Jasper, technology implies a means to an end. That is, we use technology to produce technology to achieve our goal. Therefore, to achieve high students' performance, there is a need to implement educational technologies.

Similarly, in education, instrumentalists argue that with the help of technologies such as the Internet, social media, tablets, and other smart devices students are able to access communicate with less hassle, access educational information that is beyond reach without technology availability, consume this information and share to different geographical location in no time implying openness in communication argued by [51].

\section{DEDUCTION, RECOMMENDATION, CONCLUSION}

AND

In summary, several available pieces of evidence reveal that pedagogical technologies are used as a support mechanism for the traditional educational process 'learning and teaching.' These studies present the positive and the unprecedented consequences of these technologies adoptions despite being used as a support mechanism to traditional education. The authors, therefore, deduce the potential outcome of adopting full-scale technologies for the pedagogical process. These deductions revolved around the deterministic and the instrumentalist philosophy of technology.

From the instrumentalist approach, pedagogical technologies possess some great significance to the pedagogical process in the education industry.

The benefit of adopting educational technologies is not limited to undeterred information access, increased course engagement, especially when the course has an interactive environment. It is also believed that adopting educational technologies help both students and lecturers attain a high cognitive level, support the learning process, enhance their behavior, self-esteem, and student performance $(27,28,29,30,31,32]$. 
Contrary to this view, the determinist school of thought holds that although educational technologies might be a good idea, nevertheless, warns against the potential consequences due to the autonomous nature of technology itself and the danger it presents. The potential consequences of adopting educational technologies are not limited to students' disengagement that can hinder their performance, multitasking, cyberbullying, among others.

Furthermore, the determinist view warns against the devaluation of the education industry because of the mass commercialization of education certificates from the institutions that are more concerned with a monetary return $[52,53,54]$.

From these findings, the authors conclude that pedagogical technology adoptions are significantly based on their benefits. However, to avoid unprecedented consequences, the following recommendations were put forward. These are: 1) the objectives of the educational technologies must be made open to all actors and stakeholders, 2) pedagogical technologies should be made based on institutional needs, and 3) security protocols that limit social media usage during classroom or study time, and within the school, premises should be implemented. This might be a difficult task; however, with constant trolling and measures development, there will be a breakthrough.

To better understand the conceptual effect of technology adoption for pedagogical purposes, it is advised to examine the role of technology as a mediator between students and the institution environment. The mediation approach is not being covered in this study; therefore, serving as one of the several limitations that might help us understand better the examined relationship. In light of this, further investigations are suggested.

\section{REFERENCES}

[1] Bowen WG, Tobin EM. Locus of authority: The evolution of faculty roles in the governance of higher education. Princeton University Press; 2017 May 30.

[2] Sorokin P. Social and cultural dynamics: A study of change in major systems of art, truth, ethics, law and social relationships. Routledge; 2017 Sep 29.
[3] Furedi F. Wasted: why education isn't educating. Bloomsbury Publishing; 2010 Nov 18.

[4] Nieto S. Language, culture, and teaching: Critical perspectives. Routledge; 2009 Sep 10.

[5] Fagnant DJ, Kockelman K. Preparing a nation for autonomous vehicles: opportunities, barriers and policy recommendations. Transportation Research Part A: Policy and Practice. 2015 Jul $1 ; 77: 167-81$

[6] Lee CP, Shim JP. An exploratory study of radio frequency identification (RFID) adoption in the healthcare industry. European Journal of Information Systems. 2007 Dec 1;16(6):71224.

[7] Sunding D, Zilberman D. The agricultural innovation process: research and technology adoption in a changing agricultural sector. Handbooks in Economics. 2001 Jan 1;18(1A):207-62.

[8] Briz-Ponce L, Pereira A, Carvalho L, JuanesMéndez JA, García-Peñalvo FJ. Learning with mobile technologies-Students' behavior. Computers in Human Behavior. 2017 Jul 1;72:612-20.

[9] Park SY. An analysis of the technology acceptance model in understanding university students' behavioral intention to use e-learning. Journal of Educational Technology \& Society. 2009 Jul 1;12(3):150-62.

[10] Beland LP, Murphy R. Ill communication: technology, distraction \& student performance. Labour Economics. 2016 Aug 1;41:61-76.

[11] Mwalumbwe I, Mtebe JS. Using learning analytics to predict students' performance in Moodle learning management system: A case of Mbeya University of Science and Technology. The Electronic Journal of Information Systems in Developing Countries. 2017 Mar;79(1):1-3.

[12] Schrum L, Thompson A, Maddux C, Sprague D, Bull G, Bell L. Research on the effectiveness of technology in schools: The roles of pedagogy and content. Contemporary Issues in Technology and Teacher Education. 2007 Mar;7(1):456-60. 
[13] Alavi M, Gallupe RB. Using information technology in learning: Case studies in business and management education programs. Academy of Management Learning \& Education. 2003 Jun 1;2(2):139-53.

[14] Frøland TH, Heldal I, Sjøholt G, Ersvær E. Games on Mobiles via Web or Virtual Reality Technologies: How to Support Learning for Biomedical Laboratory Science Education. Information. $2020 \mathrm{Apr} ; 11(4): 195$.

[15] Trucano M. Knowledge Maps: ICTs in Education-What Do We Know about the Effective Uses of Information and Communication Technologies in Education in Developing Countries?. Online Submission. 2005.

[16] McGloin R, McGillicuddy KT, Christensen JL. The impact of goal achievement orientation on student technology usage in the classroom. Journal of Computing in Higher Education. 2017 Aug 1;29(2):240-66.

[17] Wood E, Zivcakova L, Gentile P, Archer K, De Pasquale D, Nosko A. Examining the impact of off-task multitasking with technology on realtime classroom learning. Computers \& Education. 2012 Jan 1;58(1):365-74.

[18] Kaplan, S., \& Tripsas, M. (2008). Thinking about technology: Applying a cognitive lens to technical change. Research Policy, 37(5), 790805.

[19] Rosenberger R, Verbeek PP. Postphenomenological investigations: essays on human-technology relations. Lexington Books; 2015.

[20] Viljoen M. Embodiment and the experience of built space: The contributions of Merleau-Ponty and Don Ihde. South African Journal of Philosophy. 2010 Jan 1;29(3):306-29.

[21] Buabeng-Andoh, C. (2012). Factors influencing teachersâ adoption and integration of information and communication technology into teaching: A review of the literature. International Journal of Education and Development using ICT, 8(1).
[22] Hamidi, H., \& Chavoshi, A. (2018). Analysis of the essential factors for the adoption of mobile learning in higher education: A case study of students of the University of Technology. Telematics and Informatics, 35(4), 1053-1070.

[23] Riddell, W. C., \& Song, X. (2017). The role of education in technology use and adoption: Evidence from the Canadian workplace and employee survey. ILR Review, 70(5), 12191253.

[24] Czaja SJ, Charness N, Fisk AD, Hertzog C, Nair SN, Rogers WA, Sharit J. Factors predicting the use of technology: Findings from the center for research and education on aging and technology enhancement (CREATE). Psychology and aging. 2006 Jun;21(2):333.

[25] Kanwal, F., \& Rehman, M. (2017). Factors affecting e-learning adoption in developing countries-empirical evidence from Pakistan's higher education sector. IEEE Access, 5, 10968-10978.

[26] Peeters W. Applying the networking power of Web 2.0 to the foreign language classroom: A taxonomy of the online peer interaction process. Computer Assisted Language Learning. 2018 Nov 2;31(8):905-31.

[27] Busebaia TJ, John B. Can flipped classroom enhance class engagement and academic performance among undergraduate pediatric nursing students? A mixed-methods study. Research and Practice in Technology Enhanced Learning. 2020 Dec;15(1):1-6.

[28] Montrieux H, Vanderlinde R, Schellens T, De Marez L. Teaching and learning with mobile technology: A qualitative explorative study about the introduction of tablet devices in secondary education. PloS one. 2015 Dec 7;10(12):e0144008.

[29] Kumar, V., \& Nanda, P. (2020). Social Media as a Tool in Higher Education: A Pedagogical Perspective. In Handbook of Research on Diverse Teaching Strategies for the Technology-Rich Classroom (pp. 239-253). IGI Global. 
[30] Schmid EC. Enhancing performance knowledge and self-esteem in classroom language learning: The potential of the ACTIVote component of interactive whiteboard technology. System. 2007 Jun 1;35(2):119-33.

[31] Talley CP, Scherer S. The enhanced flipped classroom: Increasing academic performance with student-recorded lectures and practice testing in a" flipped" STEM course. The Journal of Negro Education. 2013 Oct 28;82(3):339-47.

[32] Tsay CH, Kofinas A, Luo J. Enhancing student learning experience with technology-mediated gamification: An empirical study. Computers \& Education. 2018 Jun 1;121:1-7.

[33] Cuban, L. (1986). Teachers and machines: The classroom use of technology since 1920. Teachers College Press.

[34] DeAndrea DC, Ellison NB, LaRose R, Steinfield C, Fiore A. Serious social media: On the use of social media for improving students' adjustment to college. The Internet and higher education. 2012 Jan 1;15(1):15-23.

[35] Donnelly R. Harmonizing technology with interaction in blended problem-based learning. Computers \& education. 2010 Feb 1;54(2):3509.

[36] Alghamdi A, Karpinski AC, Lepp A, Barkley J. Online and face-to-face classroom multitasking and academic performance: Moderated mediation with self-efficacy for selfregulated learning and gender. Computers in Human Behavior. 2020 Jan 1;102:214-22.

[37] Stephenson J, editor. Teaching \& learning online: new pedagogies for new technologies. Routledge; 2018 Dec 7.

[38] Winner L. Autonomous technology: Technicsout-of-control as a theme in political thought. Mit Press; 1978.

[39] Hauer, T. (2017). Technological determinism and new media. International Journal of English Literature and Social Sciences, 2(2), 239174.
[40] Cervero R. Bus rapid transit (BRT): An efficient and competitive mode of public transport. Working Paper; 2013.

[41] Fry T. Design futuring. University of New South Wales Press, Sydney. 2009:71-7.

[42] Rode P, Floater G, Thomopoulos N, Docherty J, Schwinger P, Mahendra A, Fang W. Accessibility in cities: transport and urban form. InDisrupting mobility 2017 (pp. 239-273). Springer, Cham.

[43] Bookchin M. The ecology of freedom. New Dimensions Foundation; 1982.

[44] Faber M, Manstetten R, Proops JL. Humankind and the environment: an anatomy of surprise and ignorance. Environmental values. 1992 Aug 1;1(3):217-41.

[45] DiNello, P. M., Linares, M. A., Cargill, L. E., Pointer, R. L., \& Haines, P. A. U.S. Patent No. $8,221,668$. Washington, DC: U.S. Patent and Trademark Office. 2012.

[46] Lopes AG. Single-use in the biopharmaceutical industry: A review of current technology impact, challenges and limitations. Food and Bioproducts Processing. 2015 Jan 1;93:98-114.

[47] Lynch K, Grummell B, Devine D. New managerialism in education: Commercialization, carelessness and gender. Springer; 2012 Jun 7.

[49] Jarzabkowski P, Kaplan S. Strategy tools-inuse: A framework for understanding "technologies of rationality" in practice. Strategic management journal. 2015 Apr;36(4):537-58.

[50] Leonardi PM. When flexible routines meet flexible technologies: Affordance, constraint, and the imbrication of human and material agencies. MIS quarterly. 2011 Mar 1:147-67.

[51] Knox J. The limitations of access alone: Moving towards open processes in education technology. Open Praxis. 2013 Jan 14;5(1):219.

[52] Hartmann S. The informal market of education in Egypt: private tutoring and its implications. 2008. 
[53] Johnson V. Masking Neoliberal Ideology: Teleological Framing and the" Reinvention" of Higher Education. Journal for Critical Education Policy Studies (JCEPS). 2018 Dec $1 ; 16(3)$.

[54] Latchem, C. R., \& Hanna, D. E. (Eds.). (2001). Leadership for 21st century learning: Global perspectives from educational innovators. Psychology Press.

[55] Ihde D. Philosophy of technology. InPhilosophical problems today 2004 (pp. 91108). Springer, Dordrecht. 